The University of San Francisco

USF Scholarship: a digital repository@ Gleeson Library |

Geschke Center

Philosophy

College of Arts and Sciences

2016

\title{
Anscombe, Thomson, and Double Effect
}

Thomas A. Cavanaugh

University of San Francisco, cavanaught@usfca.edu

Follow this and additional works at: http://repository.usfca.edu/phil

Part of the Philosophy Commons

\section{Recommended Citation}

Cavanaugh, Thomas A., "Anscombe, Thomson, and Double Effect" (2016). Philosophy. Paper 54.

http://repository.usfca.edu/phil/54

This Article is brought to you for free and open access by the College of Arts and Sciences at USF Scholarship: a digital repository @ Gleeson Library | Geschke Center. It has been accepted for inclusion in Philosophy by an authorized administrator of USF Scholarship: a digital repository @ Gleeson

Library | Geschke Center. For more information, please contact repository@usfca.edu. 
Anscombe, Thomson, and Double Effect

\section{T. A. Cavanaugh}

Abstract. In "Modern Moral Philosophy" Anscombe argues that the distinction between intention of an end or means and foresight of a consequentially comparable outcome proves crucial in actevaluation. The deontologist J. J. Thomson disagrees. She asserts that Anscombe mistakes the distinction's moral import; it bears on agent-evaluation, not act-evaluation. I map out the contours of this dispute. I show that it implicates other disagreements, some to be expected and others not to be expected. Amongst the expected, one finds the ethicists' accounts of action and understanding of how agent-assessment relates to act-assessment. Amongst the unexpected, one finds the moralists' views about the possibility of self-imposed moral dilemmas and allied positions concerning temporal aspects of “ought implies can.” Anscombe's employment of the distinction in act-evaluation withstands close scrutiny; Thomson's denial of it does not.

I.

Introduction. Elizabeth Anscombe introduces double-effect reasoning (double effect, DE, or DER) ${ }^{1}$ into contemporary Anglophone philosophy in "Modern Moral Philosophy."2 More

\section{${ }^{1}$ Commonly referred to as the "Doctrine of Double Effect" (DDE). I prefer "double} effect” (DE) or “double-effect reasoning” (DER). Given DE's Thomistic provenance, “doctrine” suggests to many ears a dogmatic sectarian account, not a reasonable philosophical position. Hence, for many, the name amounts to a dismissal. In Anscombe's first published reference to DE, she writes simply of "double effect." See her (1939) contribution ("The War and the Moral Law") to the two-part pamphlet (“Justice of the Present War Examined"), which she penned as a twenty-or-so-year-old Oxford undergraduate (along with Norman Daniel, who wrote the second 
precisely, Anscombe proposes that the distinction between intention of an end or means and foresight without intent of an effect of one's act (henceforth, the I/F distinction) can have crucial moral import in the evaluation of consequentially comparable actions. ${ }^{3}$

Anscombe maintains that denial (which she attributes to Sidgwick) of the distinction differentiates "old-fashioned utilitarianism" from "consequentialism" (a term she coined in "Modern Moral Philosophy," which appellation, needless to say, has taken). ${ }^{4}$ She argues that the refusal to acknowledge the distinction's ethical relevance in act-assessment leaves one to count consequences in contrast to the "intrinsic badness of this or that action." Since her introduction of the topic, we find a voluminous literature. ${ }^{6}$

part). She re-published this in G. E. M. Anscombe, Ethics, Religion and Politics, The Collected Philosophical Papers, Vol. III (Oxford: Basil Blackwell, 1981), 72-81.

${ }^{2}$ G. E. M Anscombe, “Modern Moral Philosophy,” Philosophy 33, no. 124 (1958): 1-19. Also available in Human Life, Action and Ethics: Essays by G.E.M. Anscombe, ed. Mary Geach and Luke Gormally (Exeter: Imprint Academic, 2005), 169-94.

${ }^{3}$ I focus on the debate regarding the I/F distinction's moral import in cases typically treated by $\mathrm{DE}$ - e.g., tactical bombing/terror bombing and palliative sedation/voluntary active euthanasia (or, PS/VAE). Because Anscombe and Thomson both treat of PS/VAE, I limit my attention to that duo.

${ }^{4}$ Anscombe, "Modern Moral Philosophy," 12.

${ }^{5}$ Ibid.

${ }^{6} \mathrm{DE}$ 's intercourse with the larger philosophical world continues to prove prolific. Consider, for example, that Phillipa Foot (1967) first presents the Trolley case in consideration 
In what follows, I map out neglected contours of a dispute that the deontologist Judith Jarvis Thomson has with Anscombe over DE. ${ }^{7}$ Notably, both Anscombe and Thomson oppose consequentialism. Thus, their difference over DE does not reduce to a debate over the merits of that account. Rather, as we will see, it amounts to a difference over the locus of the I/F distinction's moral import. In what follows, I show that this disagreement implicates othersboth not expected (such as one involving the possibility of moral dilemmas and how to understand "ought implies can") and those to be expected (such as divergence concerning what constitutes action).

of Anscombe's claim concerning the moral import of the I/F distinction. Regarding Foot, one notes that in her much cited article, "The Problem of Abortion and the Doctrine of Double Effect," Oxford Review 5 (1967): 5-15, she denies the ethical significance of the distinction. Years later, in a little-noted book chapter in which she considers the I/F distinction, Foot endorses it, saying: "In 'The problem of abortion and the doctrine of double effect' I argued, (wrongly, as I now think) that the distinction between direct and indirect intention was irrelevant to moral judgement." Philippa Foot, "Morality, Action and Outcome," Morality and Objectivity: A Tribute to J. L. Mackie, ed. Ted Honderich (London: Routledge \& Kegan Paul, 1985), 23-38, at $37 \mathrm{n} 6$.

${ }^{7}$ In subsequent treatments of DE, Anscombe displays ambivalence towards it - especially to the abuses to which it has been put. For a more extensive consideration of her thought, see T. A. Cavanaugh, “Abuses of Double Effect, Anscombe's Principle of Side Effects, and A (Sound) Account of Duplex Effectus," forthcoming in Anscombe and Double Effect, ed. John O'Callaghan and Craig Iffland (Notre Dame: Notre Dame University Press). 
Noting that Anscombe introduces the I/F distinction into contemporary moral theory, Thomson hypothesizes why this supposed error persists (regrettably, in her eyes):

What I refer to is a failure to take seriously enough the fact—I think it is plainly a factthat the question whether it is morally permissible for a person to do a thing is just not the same as the question whether the person who does it is thereby shown to be a bad person. ${ }^{8}$

Thomson claims that Anscombe errs in giving the I/F distinction a role in act-assessment in double effect cases. For, according to her lights, it lacks relevance in that arena. Rather, it has import in agent-assessment. (Of course, Anscombe and friends of DE more generally agree on its relevance in agent-assessment.) Let us examine this dispute and the allied matters it implicates.

II.

Two Cases: Ambiguous Intent (AI) and Revengeful Intent (RI). Consider standard DER cases involving a consenting, terminally ill patient: palliative sedation (henceforth, PS) and voluntary active euthanasia (henceforth, VAE), of which both Anscombe and Thomson treat. In PS, a physician administers a palliative-cum-lethal drug (e.g., a barbiturate) with a view to relieving the patient's pain. The barbiturate affects both the patient's pain receptors (and, thereby, relieves his pain) and also those nerves responsible for his respiration (and, thereby, kills him). In VAE, a doctor administers a lethal drug to an otherwise similarly situated patient as a means of ending pain by killing the patient. ${ }^{9}$ While it would not be a typical case of VAE, a

${ }^{8}$ J. J. Thomson, "Physician-Assisted Suicide: Two Moral Arguments," Ethics 109 (1999): 497-518, at 517.

${ }^{9}$ In PS one relieves pain, for the drug palliates. Typically, in VAE and PAS, one ends but need not relieve pain, for the drugs are lethal but not necessarily palliative. I note this difference 
physician could employ a lethal-cum-palliative drug such as the barbiturate used in PS to effect VAE.

As Anscombe herself holds, PS is ethically in the clear. ${ }^{10}$ Employing the three following criteria of DE, one can discern why. For, PS is (1) a good act (of pain relief), but for the bad side effect (premature death); (2) the agents involved intend the patient's relief from pain and need not intend the patient's death (either as an end or as a means) while they do foresee it; and (3) the good at issue (relief of agonal pain at the end of life) compares favorably to the bad effect (causing the patient's death earlier than it would have otherwise occurred). ${ }^{11}$ Thus, in accordance with DER, a terminally ill patient, his family and physician ethically may treat his otherwise intractable pain with a barbiturate that foreseeably also causes his death.

By contrast (and as Anscombe herself holds), administering a lethal drug to a consenting, terminally ill patient in order to kill her and, thereby, end her pain (VAE) is not ethically in the clear. ${ }^{12}$ For, while consequentially similar to PS, such an act instances the deliberate killing of a

for the sake of precision, not in order to put weight upon it. In physician-assisted suicide (PAS), a practice allied to VAE, the physician writes a prescription for a lethal drug which the patient fills and takes at her discretion.

${ }^{10}$ See, e.g., Anscombe, "War and Murder," in Ethics, Religion and Politics, The Collected Philosophical Papers, vol. 3 (Oxford: Basil Blackwell, 1981), 51-61, at 54.

${ }^{11}$ For a more extended consideration of the DER criteria, see T. A. Cavanaugh, DoubleEffect Reasoning: Doing Good and Avoiding Evil (Oxford: The Clarendon Press, 2006), 26-37.

${ }^{12}$ G. E. M. Anscombe, "Murder and the Morality of Euthanasia," in Human Life, Action 
harmless person, and is, thereby, unjust homicide.

Of course, given the comparable consequences and the observable similarity of PS and VAE — as noted above, one could accomplish VAE employing the same drug used in PS—some moralists (including Thomson) find this claim dubious. For how could, e.g., the giving of the same palliative-cum-lethal drug to similarly situated patients be ethically and legally in the clear in PS and be morally and legally out of bounds in VAE if all that differs are the intentions of the agents? More pointedly, how can this make a difference to the legal and moral evaluation of the relevant acts? (For the time being, we will put the law to the side and focus on ethics.) ${ }^{13}$

and Ethics: Essays by G. E. M. Anscombe, 261-77.

${ }^{13}$ Thomson writes that she knows of no case other than the contrast between PS and VAE in which the law regards two consequentially comparable acts as illegal/legal based on the $\mathrm{I} / \mathrm{F}$ distinction (Thomson, "Physician-Assisted Suicide," 515.) Indeed, the distinction proves crucial legally. To provide but one signal example found in U.S. Constitutional law that illustrates the point, consider how to read the first words of the U.S. Constitution's First Amendment:

Congress shall make no law respecting an establishment of religion, or prohibiting the free exercise thereof; or abridging the freedom of speech, or of the press; or the right of the people peaceably to assemble, and to petition the government for a redress of grievances.

Were a legislator to make a law with the intention of establishing or of restricting the free exercise of a religion, etc., such a law would, thereby, by that very intent, be illegal. Absent such an intent, a law that has the effect of establishing or prohibiting can be legal, other criteria being met (into which I will not here go). For a consideration of U.S. Constitutional casuistry 
As noted, Thomson proposes that the I/F distinction contrasts the agents, not the acts. She challenges the I/F distinction's moral relevance in the evaluation of acts by means of two cases, as follows:

According to PDE [the principle of double effect], the question whether it is morally permissible for the doctor to inject a lethal drug turns on whether the doctor would be doing so intending death or only intending relief from pain. That is just as absurd an idea ... [as to think that a difference in the doctor's intent should make a legal difference, as it in fact does - Thomson thinks the law errs on this point]. If the only available doctor would inject to cause the patient's death, or is incapable of becoming clear enough about her own intentions to conclude that what she intends is only to relieve the patient's pain, then — according to PDE — the doctor may not proceed, and the patient must therefore continue to suffer. That cannot be right.

If a doctor will inject her patient intending his death as an end and, moreover, wants his death only because his death will constitute revenge, then that does matter morally. But we have to be careful about how it matters. I suggest that it has no bearing on whether it is morally permissible for her to act. Whatever her intention may be, the patient, we are supposing, desperately wants her to inject the drug....

That she will inject for that reason matters morally, not by way of fixing that it is morally impermissible for her to proceed, rather by showing something morally bad

analogous to DER, see Cavanaugh, Double-Effect Reasoning, 192-5; see also, Edward Lyons, “In Incognito_-The Principle of Double Effect in American Constitutional Law," Florida Law Review 57 (2005): 469-563. 
about her. $^{14}$

We have two cases involving the only available doctor. First, a case in which the physician injects revengefully to kill the patient, not to relieve the patient's pain (which, for ease of reference, let us call the case of revengeful intent or RI). Second, a case in which the doctor cannot get clear about her intention being only to relieve the patient's pain and not to kill (which, for ease of reference, let us call the case of ambiguous intent or AI). ${ }^{15}$ Although Thomson puts AI to the side, I address one issue she raises with AI before proceeding to consider RI. Namely, what does one reliant upon DE have to say about the only available physician being unable to rule out intent of the bad as operative in her acting?

To entertain this question, let us further articulate AI along the lines Thomson suggests.

${ }^{14}$ Thomson, "Physician-Assisted Suicide: Two Moral Arguments," 515-16 (emphases in original).

${ }^{15}$ For the sake of clarity, while AI may instance VAE, RI does not (nor does Thomson propose them as instances of VAE). For, as I understand Thomson, in AI the physician injects in order to palliate and may be injecting in order to kill. Since Thomson does not specify why the doctor in AI intends to kill (revengefully or not), I also leave that unspecified. We are not entirely clear why she intends to kill. Does she do so to end the patient's pain? But, the drug will do that, and she does intend palliation, so that seems unlikely. Or, does she inject as constitutive of revenge? Whatever the case in $\mathrm{AI}$, in $\mathrm{RI}$ the physician clearly injects in order revengefully to kill, not to end the patient's pain. In the paradigmatic case of VAE, the physician (without revenge) injects to kill and, thereby, end pain. However, since Thomson uses AI and RI to argue against DER's contrasting PS from VAE, I attend to them. 
We are to imagine a physician who has two morally salient intents, one to relieve her patient's pain and one to kill her patient. Were she to inject the patient with the drug, she knows she would do so with the intent to relieve the patient's pain. However, she cannot conclude that were she to inject, she would do so only to relieve the patient's pain. She might also inject in order to kill her patient. Given this opacity concerning how operative her intention of the bad would be, Thomson holds that DE tells her not to inject. For she very well may be injecting (in part) with the intent to kill, violating the above-noted second criterion of DER.

I concede what I take to be at least one of Thomson's points made by this case. While DE does not require that the agent have no other intentions besides the good effect, it does require that the agent not intend the foreseen bad effect (either as an end or means). In her use of "only to relieve the patient's pain" Thomson focuses our attention on this very requirement—DE's (second) criterion. ${ }^{16}$ As Thomson (correctly) puts it, DER requires that an agent can become "clear enough about her own intentions." ${ }^{17}$ In other words, she must be able reasonably to judge that she intends the good and does not intend the bad. Of course, an agent may lack such an adequate view. She may not have sufficient clarity about the intentions in accordance with which she acts. Other things being equal, DE—as Thomson suggests—would advise the agent to refrain from acting because she cannot reasonably rule out homicidal intent as operative.

However, are other things equal? No. To see the relevant difference, consider more closely what reasonable judgements the physician in AI can make concerning her intentions.

\footnotetext{
${ }^{16}$ Ibid., 516.

${ }^{17}$ Ibid.
} 
Importantly, she reasonably judges herself as having the intent to palliate her patient's pain. Thus, in this respect, she reasonably judges herself as seeking to act well by her patient. Were she to act, her act would in fact be one of palliating her patient's pain. By contrast, the physician in RI is entirely morally lost. For she lacks the normative intent to relieve her patient's pain while hating her patient. Indeed, were she to act, her act would not even be one of killing in order to end pain; rather, it would be one of revengeful homicide.

Concerning AI, consider the doctor's ethically problematic homicidal intent. She cannot reasonably rule this intent out as operative in her action. Importantly, neither can she reasonably rule it in. It might be operative; but, then again, it might not. This is not the same as reasonably judging herself as intending the bad at issue (as is the case in RI). Were she reasonably to judge herself as intending her patient's death (as the physician in RI must), a moralist employing DE would have to advise her not to act. However, given (1) her confident judgment that her intent to relieve her patient's pain would be operative, (2) her doubt concerning how operative her homicidal intent would be, and (3) her being the only available physician, an ethicist employing DE could advise her to administer the barbiturate. (Needless to say, were there a physician not morally compromised as is the physician in AI, the ethicist relying on DE would counsel that he care for the patient.) Thus, closer consideration of AI suggests that it leaves the I/F distinction unscathed. Having addressed the challenge AI poses, let us consider the morally salient intentions present (and absent) in AI and RI with a view to considering the difficulty RI presents for DE.

The important relation between doctoring and palliation (preserved in AI) suggests three questions that point to a substantive issue that Thomson entirely neglects. First, what has led the 
doctor in AI to have the intention to palliate her patient's pain? Second, and an associated question, what has led the doctor in RI not to have the intent to relieve her patient's pain? Third and finally, what explains the physician's intent revengefully to kill her patient in RI? An investigation into the history of these morally salient intentions (and lack of palliative intent in $\mathrm{RI})$ instanced in these cases suggests that the physician in RI faces a self-imposed moral dilemma. (The physician in AI has compromised herself, but she has not put herself into a moral dilemma; she can still act ethically, as argued above.)

Consider the genesis of the physician's intention in AI to relieve her patient's pain. Being a physician involves having such an intention towards one's patient. A physician as a physician purposefully, deliberately, or, in other words, intentionally relieves her patient's pain. Indeed, palliative care is a medical specialty. For some physicians, it is all they do. For all physicians, it is one act that, when done, is to be done with that very intent. "Cure sometimes, treat often, comfort always" serves as a medical aphorism indicating the sine qua non that palliation represents for a physician. To palliate is to act as a physician par excellence. Other things being equal, to palliate instances a physician's office, or, ethically, her professional duty. Thus, our physician in AI has the intention to palliate insofar as she acts as a physician. She comes by the intent honestly as an essential part of her noble profession. Because Thomson does not elaborate upon the intent of the physician in AI to kill her patient (is it to end the patient's pain? is it for the sake of revenge?), let us consider the physician in RI whose intent Thomson articulates more fully.

In contrast to the physician in $\mathrm{AI}$, the doctor in RI lacks the normative intent of relieving her patient's pain. Somehow, at least with respect to this patient, she has lost her orientation 
towards one of the essential goals of doctoring: palliation. In this respect and towards this patient, she therefore no longer acts as a doctor, for the goal of palliation partially defines her profession. Presumably, her loss of this intent has something to do with her acquisition of a revengeful intent towards her patient. What of a physician's revengeful intention? How does that figure in doctoring?

Thomson elaborates upon RI by specifying that the doctor wants her patient's death in itself, as constitutive of revenge. She speaks of the doctor as injecting the lethal drug "out of hatred." 18 That a physician harbors revengeful homicidal intent towards her patient merits comment. Concerning the genesis of this malicious intent, Thomson does not give us much to go on. She does, however, indicate that the revengeful intent shows us something "morally bad about [the physician]"19 who has it; she is a "bad person." ${ }^{20}$ More importantly, in respect of this intent she is a bad doctor. For a doctor as a doctor ought not to seek revenge upon her patient, nor ought she hate her patient. The physician ought not to have this intent towards this patient. So, let us proceed understanding the physician's revengeful intent as wrongful—as one would reasonably expect.

Accordingly, there is some narrative in terms of which the physician by a previous wrongful act (or acts) came by this intent towards this patient. This history bears on our analysis of the act in question in RI. For in light of the genesis of the malicious intent, one plausibly
${ }^{18}$ Ibid., 517.
${ }^{19}$ Ibid., 516.
${ }^{20}$ Ibid., 517. 
thinks that the physician has gotten herself into a situation such that she cannot now do the right act; namely, relieve her patient's pain as an act of palliation, not as an act of homicidal revenge. Thomson does not consider this signal possibility.

Rather, she assumes that an agent can always do the right deed. Therefore, she must treat intent as irrelevant in the determination of the deed as right. For, otherwise, the agent in RI would not be able to do the right deed. She would face a moral dilemma. Thomson, however, dismisses the possibility of an agent facing two incompatible oughts (or, in other words, a moral dilemma):

I think myself that it was not merely odd but patently incorrect to think that

(3) I ought to give $\mathrm{C}$ a banana

and

(4) I ought to give D a banana

can both be true compatibly with my having only one banana; I think we simply do not use the English word "ought" in such a way that this is so. In any case, I will not. I will throughout so use "ought" that it cannot be the case that I ought to do alpha and ought to do beta where I cannot do both alpha and beta. ${ }^{21}$

Remarkably, Thomson rejects the possibility of incompatible oughts as "patently incorrect" even as not in keeping with English usage (at least one interpretation of "damned if you do; damned if you don't" suggests otherwise). Yet, this offhand rejection of moral dilemmas, although distinct from denying the I/F distinction, instances an allied and implicated disagreement between her and those friendly to the distinction.

\footnotetext{
${ }^{21}$ J. J. Thomson, The Realm of Rights (Cambridge: Harvard University Press, 1990), 86.
} 
Along the lines suggested by Thomson, this particular challenge to the I/F distinction goes by way of an insistence that "ought implies can." Let us turn to consider this objection more fully. ${ }^{22}$ How does the moral truism “ought implies can” stand vis-à-vis our physician in RI? If

${ }^{22}$ W. D. Ross weighs in on the issue, as follows:

That action from a good motive is never morally obligatory follows (1) from...'I ought' implies 'I can'. It is not the case that I can by choice produce a certain motive....in myself at a moment's notice, still less that I can at a moment's notice make it effective in stimulating me to act. I can act from a certain motive only if I have the motive; if not, the most I can do is to cultivate it by suitably directing my attention or by acting in certain appropriate ways so that on some future occasion it will be present in me, and I shall be able to act from it. My present duty, therefore, cannot be to act here and now from it. (W. D. Ross, The Right and The Good (Oxford: The Clarendon Press, 1930), 4-5, original emphases.)

Ross uses "motive" to refer to intent of one's end. In the case at hand, it would be the intent of revenge as an end, per Thomson's usage. Ross draws attention to the temporal aspects of an agent's intentions - referring to "some future occasion"- only to neglect the very import he suggests: namely, that had one in the past cultivated an intent, one would here and now be able to act on it (as one ought). (The same of course holds for not cultivating certain intents.) On this issue of an agent's occurrent inability to control her intentions, indicating the unsuitableness of reliance upon intent in act-assessment, see also Jonathan Bennett, The Act Itself (Oxford: The Clarendon Press, 1995), 195-6 and T. M. Scanlon, Moral Dimensions: Permissibility, Meaning, Blame (Cambridge: Belknap Press, 2008), 56-62. Joining Thomson, Bennett and Scanlon both 
DE is correct, she ought to intend to relieve her patient's pain and ought not to intend revengefully to kill her patient. She has, however, somehow gotten herself into such a state that she cannot here and now (occurrently) do so. She can only inject the palliative-cum-lethal drug with the intent of revengefully killing or refrain from doing what she ought to do as a physician (relieve this patient's agonal pain). If ought implies can, then it appears as if the DE moralist errs. For our agent cannot occurrently rid herself of her malicious intent. Nor can she occurrently acquire the intent to palliate required of her as a physician. I concede the point concerning her current inabilities.

One reasonably thinks, however, that while our agent cannot here and now rid herself of the objectionable intent, there was a time when she was able to avoid acquiring it. "Ought implies can" applies immediately to that past time and mediately here and now. (The same holds for her loss of the intent to palliate.) Thus, the claim (arising from DE) that the physician in RI faces a moral dilemma does not violate the noted moral truism. It does, however, suggest that we expand our ethical investigations beyond the beguiling putatively all-encompassing "now."

Doing so enables a moralist to acknowledge that an agent can so act in the past as to become incapable of right action now. Considering that past moment, Thomson might reject the attribution of the wrongness to the act, claiming it is applicable only to the agent. Regardless, the preceding establishes that that move would amount to mere assertion. More importantly, it would

make this move against the I/F distinction's use in act-analysis without any consideration of the history of an agent's intentions and the (presumptive) control she exercises over intentionformation. 
neglect the historical character of human agency and the attending temporal aspects of "ought implies can."

Our inquiry into the genesis of the physician's intentions indicates a complexity Thomson does not acknowledge. According to the overarching moral theory of which DE serves as a part, the physician in RI faces a moral dilemma of her own making. She can either kill her patient revengefully (an act ruled out of bounds by malice) or forego the obligatory act of palliating her patient's otherwise intractable pain (a violation of a serious obligation). The physician wrongs whether she injects or not. In light of the egregious waywardness of a physician who can palliate only by intending to kill her patient revengefully, why would this result boggle one employing a sound ethic? A moralist with a realistic imagination and a sensitivity for the intricacy of the moral life will not find the possibility of a self-inflicted moral dilemma obviously incorrect. Indeed, to take but one example, Aquinas — with whom DER originates — considers self-imposed moral impasses plausible. ${ }^{23}$

${ }^{23}$ Aquinas discusses moral perplexity. He distinguishes simple perplexity (the possibility of which he denies) from what we might call conditional perplexity that one causes oneself, the possibility of which he asserts. Hence, I refer to self-imposed moral dilemmas. In Aquinas, see, for example, ST I-II, q. 19, a. 6 ad3; II-II, q. 62, a. 2, obj2; III q. 64, a. 6 ad3; and de Veritate, 17, 4 ad8. For a thorough consideration of Aquinas's account and a treatment of the (eighteen) texts in which Aquinas addresses moral dilemmas, see M. V. Dougherty, Moral Dilemmas in Medieval Thought: From Gratian to Aquinas (Cambridge: Cambridge University Press, 2011), ch. 4. I am not aware of Anscombe addressing moral dilemmas per se. An extensive reading of 
Consider Aquinas, who contemplates another instance of an agent's doing an obligatory deed but only for the wrong reason:

there is no inconvenience if something being supposed, a man is not able to avoid wrongful action; just as, supposing the intention of vainglory, he who is obligated to give alms is not able to avoid acting wrongly: for if he gives from such an intention, he acts wrongly; but if he does not give, he violates his obligation. ${ }^{24}$

Concerning the logic of such an act, Aquinas notes:

just as in syllogisms, given one error it is necessary that others follow; so also in morals, one error posited, from necessity others follow..$^{25}$

her work in ethics, however, nowhere suggests the denial of moral dilemmas. Her affinity for Aquinas's ethics suggests she would find them possible. More importantly, in a theological text she explicitly asserts that "sometimes the same thing both ought to be and ought not to be" and that the "identity of something that both ought to be and ought not to be is not impossible." G. E. M. Anscombe, "Sin," in Faith in a Hard Ground, ed. Mary Geach and Luke Gormally (Exeter: Imprint Academic, 2008), 115-56, at 145.

${ }^{24}$ de Veritate, 17, 4, ad8:

Et hoc non est inconveniens, ut aliquo supposito, homo peccatum vitare non possit; sicut supposita intentione inanis gloriae, ille qui tenetur eleemosynam dare, peccatum evitare non potest: si enim dat ex tali intentione, peccat; si vero non dat, transgressor est.

${ }^{25}$ Aquinas, ST I-II, q. 19, a. 6, ad3: "sicut in syllogisticis, uno inconvenienti dato, necesse est alia sequi; ita in moralibus, uno inconvenienti posito, ex necessitate alia sequuntur." St. Thomas thinks that (at least in this instance) the individual who got himself into moral perplexity 
Given the absurdity of a doctor who can only palliate her patient's pain via a revengeful homicidal intent, another absurdity must follow: to act or not to act wrongs the patient. While Thomson dismisses such a (coherent) judgement, she proposes that the agent in RI merits a negative evaluation. Let us examine this claim more closely to see if it can, as she assumes, comport with her denial of a negative assessment of the related act.

III.

Bad Agent. Thomson acknowledges that the agent in RI merits a negative evaluation in terms of the I/F distinction. No doubt, one employing the distinction agrees. The dispute concerns the use of the distinction to evaluate acts, too. Thomson proposes that we should say that the doctor in RI "is bad" while what she does is "morally permissible."26

How is the agent in RI bad? Her badness concerns her in a certain respect. Paraphrasing Anscombe's discussion of acts, one might say that an agent is bad (or good) "under some description. ${ }^{, 27}$ She may exercise agency in many capacities: as an employer, a mother, or a pianist. Her badness does not concern these roles. Although nothing hinges on it, having acknowledged that she is bad as an agent, Thomson would presumably also hold her to be bad as

can get himself out; namely, by "dismissing the bad intention," "potest intentionem malam dimittere." Hence, we ought not think that a moral dilemma (as Aquinas conceives of it) is entirely inescapable; it is, however, on the supposition of the bad intent.

${ }^{26}$ Thomson, "Physician-Assisted Suicide," 517.

${ }^{27}$ G. E. M. Anscombe, Intention (Cambridge: Harvard University Press, 2000) section 19 , 29. 
a doctor (who ought to seek to relieve her patient's pain and not revengefully to kill). Thus, she is bad as an agent and, specifically, as a physician. (One could make all of the substantive points that follow without reference to her as a physician. It is worthwhile, however, methodologically and substantively to note that agency typically has specificity. One is a good or bad kind of agent, not simply a good agent or a bad agent. Again, one exercises agency "under some description.") Now, what does it mean to be bad as an agent and as a doctor? What is an agent bad at? What is a physician bad at? Presumably, an agent is one who does acts; a doctor one who does medical acts.

Consider, a potter makes pots; a ballerina dances. In the case of potting we have a product distinct from the activity; in the case of dancing we have the activity. The bad potter makes bad pots and the bad ballerina dances poorly—or, if I may so speak, makes bad dances. ${ }^{28}$ In both instances, the defect in the agent as an agent indicates a defect in the product made or in the act performed. Because defects in the making of actually distinct products (e.g., pots) are not applicable to the acts we consider, put the making of a product case to the side. Let us consider

${ }^{28}$ When it comes to products, the reverse need not hold. As Chaucer shows in Canterbury Tales, the worst poem can be the work of the master poet-consider Sir Thopas. Of course, as Aristotle famously notes, excellent agency at times excludes acting badly—such that the generous person cannot act stingily, nor the virtuous person viciously, in respect of that in terms of which he is virtuous (Aristotle, Nicomachean Ethics, VI, 5, 1140b24). We, however, move in the opposite direction, looking into the viability of assessing an agent negatively while not assessing the agent's act negatively (at least as far as permissibility). 
only dancing-like cases.

Curiously and without comment, Thomson asks us to evaluate an agent as an agent negatively while not evaluating the agent's act negatively. Yet, paradigmatically, even analytically, defects in agent as agent suggest defects in acts as acts. For agency is the making of acts. A defective agent implicates a flawed act. Thomson denies the implication; the advocate of DE insists upon it. What of this?

At this apparent impasse, one notes that Thomson holds that while the agent in RI is bad, her act is permissible. For an act to be permissible is for it to be ethically in bounds. It may lack perfection, by having some bad-making features, while still being within the boundaries that ethics requires of it. Perhaps Thomson would be willing to concede the analytical point that a negative assessment of an agent makes for a negative assessment of the corresponding act while holding that the negative assessment of the act need not amount to impermissibility. It might, rather, indicate a defect in the act that falls short of ruling it out of bounds. If we wish further to advance the conversation, I suggest we take this tack. It directs our attention to the issue of permissibility. Let us consider this criterion.

Roughly, Thomson holds that permissibility of an act is to be understood in terms of claims that individuals have against agents not to be caused harm. In the case of RI, the patient has a claim not to be revengefully killed by the physician while also having a claim to pain relief. Of course, the two claims conflict in the case at hand. For, given this physician's intention, pain relief cannot occur except as coincident upon revengeful killing. The fulfillment of one claim involves the infringement of another. How does Thomson determine permissibility when it comes to the infringement of a claim? She proposes, "It is permissible to infringe a claim if and 
only if infringing it would be sufficiently much better for those for whom infringing it would be good than not infringing it would be for the claim holder." 29

In RI, the individual patient is at once the one whose claim is infringed and the one benefitted by the infringement. Regarding such a case, she suggests we determine permissibility in terms of "how bad things are for the claim holder if the claim is infringed." 30 Well, how bad are things for the patient? Which is worse, to be revengefully albeit painlessly killed by one's physician or to die in unrelieved pain? Perhaps most of us would opt for being painlessly but revengefully killed. Regardless, who would in turn say that the doctor's act of revengeful killing is, thereby, sans phrase, ethically permissible?

Consider this point from another vantage: if "bad" correctly assesses the physician in RI (as it does), then would not "ethically out of bounds," "wrong," even "impermissible" correctly assess the corresponding act? To consider one a "bad person," as Thomson (rightly) regards the physician in RI, amounts to a significantly negative character evaluation. The doctor in RI has serious defects. She both lacks the normative intent to relieve her patient's pain and bears revengeful homicidal intent towards her patient. These are not minor flaws in a physician. Hence, she merits the evaluation Thomson assigns to her: bad. As argued, a defect in the agent implicates a defect in the act. By parity of reasoning, a grave defect in the agent implicates a grave defect in the act. "Bad" as said of an agent would seem to implicate "impermissible" as said of an act.

\footnotetext{
${ }^{29}$ Thomson, The Realm of Rights, 174.

${ }^{30}$ Ibid., 175.
} 
Thus, if Thomson wishes to maintain the act's permissibility, she needs to lessen the severity of her judgement concerning the physician. Yet, something has gone seriously amiss with the physician in RI; Thomson duly judges the doctor as bad. A less severe character evaluation would err. Hence, Thomson cannot at once assess the agent as bad while not having a correspondingly severe negative judgment concerning her act, such as "impermissible" or its moral equivalent.

By contrast, Anscombe and others who employ the I/F distinction would maintain that, in RI, just as "bad" correctly assesses the agent, so also "malicious," "wrong," "ethically out of bounds," and "impermissible" correctly evaluate the agent's act. In any case, we here come to an impasse between the disputants. How shall we proceed? Let us (albeit briefly, due to the extensive treatments each offer as well as a need for brevity) consider their accounts of action, a topic upon which one would expect them to differ, as they do-dramatically.

IV.

Cause or Agent? The dispute concerning the I/F distinction (unexpectedly) implicates a difference concerning moral dilemmas and temporal aspects of "ought implies can.” Less surprisingly, it involves differences over what constitutes an act. In Intention, Anscombe articulates an account of human action as characteristically intentional. In doing so, she stands in a long tradition (that includes, amongst many others, Aristotle, Aquinas, Bentham, and Mill). ${ }^{31}$

\footnotetext{
${ }^{31}$ See, e.g., Aristotle, Nicomachean Ethics, III, chs. 1-5; Aquinas, ST I-II q. 1. a.1. For a consideration of how Aristotle's account of action relates to the I/F distinction, see T. A. Cavanaugh, “Aristotle's Voluntary/Deliberate Distinction, Double Effect and Ethical
} 
In Intention Anscombe speaks of our "special interest in human actions," or ethics. ${ }^{32}$

Because intention defines uniquely human acts, when we do ethics, we have a particular interest in an agent's intentions - if only to determine the subject matter of our investigation (actions). One who thinks that intention in part distinguishes what ethics studies (acts) from phenomena associated with humans that ethics does not investigate (digestings, fallings, and so on) also reasonably thinks that differences in intention can make for differences in act-evaluation. For as intent makes an act an act, differences in intent make for differences in acts—presumably including evaluative differences. Given Anscombe's extended argument for intention as partially constitutive of action, one sees grounds for her acknowledgment of the I/F distinction's role in act-assessment.

While there is a theoretical elegance and immediate plausibility in an account (like Anscombe's) that holds that what makes an act to be an act also plays a role in what makes it to be a good or a bad act (just as what makes an $x$ to be an $x$ enters into an account of what makes it to be a good or a bad $x$ ), one could (with argument) hold that intent does constitute an act as an act while not holding that intent serves in the ethical assessment of an act. (Here, for example, Mill appears to diverge from Anscombe. $)^{33}$ Rather, one might focus on an intentional act's

Relevance," International Philosophical Quarterly 54 (2014): 367-78. For a brief consideration of Mill (and Bentham) on intent as defining action, see, e.g., John Stuart Mill, Utilitarianism, $2^{\text {nd }}$ ed., ed. George Sher (Indianapolis: Hackett Publishing Co., 2001), 18-9n2.

\footnotetext{
${ }^{32}$ Anscombe, Intention, section 46, 83.

${ }^{33}$ John Stuart Mill, Utilitarianism, 18-20.
} 
consequences. Indeed, as noted at the outset, Anscombe claims this is precisely what one would reasonably do if one were (unreasonably) to deny the import of intention in act-evaluation by denying the I/F distinction. This, however, does not instance the approach that Thomson takes. Rather, she has a radically idiosyncratic account of what an act is.

Thomson does not regard intent as crucial to identifying an act as an act. Indeed, she lacks interest in such an identification or in what many would refer to as an "act." Rather, she proceeds backwards, as it were, from, e.g., a harmful effect upon one individual which can be causally associated with another individual. She then speaks of the latter individual as an "agent," using the word in a highly deracinated fashion. This salient difference with Anscombe (not to mention Bentham, Mill, let alone Aquinas and Aristotle) in part explains their dispute over the I/F distinction.

At the very end of her book on acts, Thomson (remarkably) speaks of one who would make "animatedness a requirement for agency." Of such a thinker, she goes on to say:

I suspect that [such a one]... simply does not find the notion "agency" I have been attending to of interest—what he wants is an account of the other notion "agency," the one according to which an event does not have an agent, and is not an act, unless it involves intentionality. Which of the two notions "agency" is of greater interest, I cannot say, and do not now really care. ${ }^{34}$

By "intentionality," Thomson does not mean only fully formed intent; she means psychological elements of human action - broadly, knowing and wanting, or voluntariness. Noting this

${ }^{34}$ J. J. Thomson, Acts and Other Events (New York: Cornell University Press, 1977), 253 (original emphasis). 
alternative account of agency (while not acknowledging its near normative character as the account of agency), Thomson continues, saying:

I cannot forbear drawing attention to the fact that it is by no means obvious that the notion 'agency' I have not dealt with is any more important for ethics than is the notion 'agency' I have dealt with. No doubt a great many good acts and a great many evil acts are intentional, and a moral philosopher does need to know something about what intentionality is. But in the first place, what we are responsible for is by no means restricted to what we bring about in a way that involves intentionality. And in the second place, it is a plausible hypothesis that causings will turn out to be central, and intentionality at most peripheral, to a theory of rights - i.e., to a theory about what we have a right to do and why we have a right to do it. ${ }^{35}$

Although her name appears nowhere in Thomson's work on acts, Anscombe is the contemporary thinker who most completely attends to the here curiously named "other notion of agency" (and thus founds the modern discipline of action-theory). Thomson neglects agency to focus on causality. As she tells us above, she does so because her principal interest is a theory of rights in which we have claims upon others, e.g., not to be caused harm (not to have certain effects happen to us which are affiliated with others as causes). By focusing on causality and not agency (or human action), Thomson advances a properly legal notion of strict liability. She errs, however, in applying this account broadly to morality.

7 To see this, consider an example — call it "Parcel"- that Anscombe offers: "Suppose I am 8 a parcel—I mean I've been made up into a parcel—and by sheer accident I get set rolling down a

\footnotetext{
${ }^{35}$ Thomson, Acts and Other Events, 253n1.
} 
1 hill in such circumstances that I kill someone by knocking him over into the path of a rapid

2 vehicle - that's not a human action on my part." ${ }^{\prime 36}$

${ }^{36}$ G. E. M. Anscombe, "Medalist's Address: Action, Intention and 'Double Effect,"” Proceedings of the American Catholic Philosophical Association, LVI (1982): 12-25, at 21; also available in Human Life, Action and Ethics: Essays by G.E.M. Anscombe, 207-26, at 210. 
Anscombe (surely correctly) holds that she does nothing morally wrong in Parcel because she does nothing at all. She does not act; therefore, there is no act to evaluate. ${ }^{37}$

Thomson, by contrast, would claim that Anscombe infringes the right of the passerby not to be killed. According to Thomson, what Anscombe does is morally impermissible. Here is Thomson on an analogous case:

Day's End: B always comes home at 9 P. M. and the first thing he does is to flip the light switch in his hallway. He did so this evening. B's flipping the switch caused a circuit to close. By virtue of an extraordinary series of coincidences, unpredictable in advance by anybody, the circuit's closing caused a release of electricity (a small lightning flash) in A's house next door. Unluckily, A was in its path and was therefore badly burned. ${ }^{38}$ Thomson holds that B (morally) ought not to flip the switch. If B does, B infringes a claim of A's. Her assumption that B's mental states cannot make a difference to act-evaluation leads her to this odd position. She holds it would be "weird in us" to say, "Look B, we know something that you don't know. If we tell you, then it will be true to say that you ought not flip the switch, but not if we don't tell you." 39 She does not acknowledge that were B to act with such knowledge, B would thereby perform an act that (now) includes voluntarily burning A. For, as Anscombe more than adequately shows in Intention, acts occur under descriptions themselves partially determined by what the agent knows himself to be doing and seeks to do. (Thomson appears entirely innocent of Anscombe's account.)

\footnotetext{
${ }^{37} \mathrm{I}$ here put to the side a complication that is not at issue: i.e., omissions.

${ }^{38}$ Thomson, The Realm of Rights, 229.

${ }^{39}$ Ibid., 233.
} 
Concerning the larger issues involving the voluntary and the intentional illustrated in Day's End and Parcel, two points come to mind. First, one must distinguish legal from moral matters. Anscombe might be legally responsible (civilly but not criminally) for the death of the man in Parcel. That is, in many jurisdictions (e.g., in the U.S.) the man's family could legally hold Anscombe financially responsible for the death of their beloved. Indeed, insurance against accidents (personal liability insurance which covers one's non-agential or merely causal effects upon others) serves precisely this purpose. Notably, it does not insure one against the intentional infliction of harm (against one's performance of criminal acts). Rather, it is, as the name often given to it indicates, insurance against accidents. Emphatically, however, from the standpoint of any sound morality or ethic, Anscombe in the parcel case is not at all responsible for the man's death. For, Anscombe as moral agent (in any tenable sense) did not kill the man; rather, a parcel did. (All the same points hold concerning B in Day's End.)

Second, while it may be true, as Thomson above claims, that an account of causality serves a legal theory of rights, a moralist who relies on such an account mistakes legal relevance for ethical relevance. Concerning Day's End, Thomson entirely misconstrues ethics' subject matter as an individual's causal relationship with salient good and bad effects (as she would were she to employ the causal account of responsibility to Parcel). By contrast, ethics concerns the voluntary - that which one relates to as a knowing willing cause. That which is not voluntary lacks moral relevance. Since the bad outcomes in Parcel and Day's End lack voluntariness, they lack ethical import. For only the voluntary has moral significance. (As Anscombe shows in Intention, intent instances especially robust voluntariness.)

Thomson's disregard for ethics' focus upon knowing-willing agency (or human agency) 
comports with her tendency not to mark much of a distinction between legal rights and moral rights. Here she is, downplaying the contrast:

Anyone who likes can at the end try to construct an account of what might plausibly be meant by the terms "moral rights" and "legal rights" under which the genus rights can be seen as having species appropriately named in those ways, but what interests us is the genus rights itself — as I will put it throughout, what interests us is people's rights. ${ }^{40}$

Thomson herself sees little reason to contrast legal from moral rights or law from morality. However, law and morality sometimes do differ importantly. For example, as noted, they differ concerning responsibility. Ethics does not have strict liability; it is entirely a legal phenomenon. Because of it, the law - in addition to having an account of criminal liability that attends to the mental elements of human acts (similar to that of morality) — has an account of purely causal responsibility. ${ }^{41}$ In terms of its account of purely causal responsibility, the law can hold Anscombe qua parcel responsible for the man's death. One errs grossly, however, if one thinks that Anscombe has a scintilla of ethical responsibility in Parcel. (The same holds, of course, for B in Day's End.)

V.

Conclusion. The preceding indicates that the dispute between Anscombe and Thomson

40 Thomson, The Realm of Rights, 76.

${ }^{41}$ In criminal law we have the principle "actus non facit reum, nisi mens sit rea." The doing does not make the crime without the mental element (mens rea); of course, the same holds in ethics. 
implicates other matters, particularly a moralist's (1) stance concerning the possibility of selfimposed moral dilemmas, (2) understanding of "ought implies can," (3) conception of how the evaluation of an agent relates to the evaluation of his act, and, of course, (4) account of action. Concerning each of these matters, reflection shows that the $\mathrm{I} / \mathrm{F}$ distinction as applied to actevaluation has much to recommend it. Contra Thomson, it is not from "lack of imagination" or a "desire for simplicity" that one acknowledges the I/F distinction's relevance in act-evaluation. ${ }^{42}$ Rather, ethicists who understand the I/F distinction's full import evidence robust imagination coupled with an appreciation for morality's complexity.

I conclude by noting Anscombe's apt advice found in "Modern Moral Philosophy": "It is not profitable for us at present to do moral philosophy; that should be laid aside at any rate until we have an adequate philosophy of psychology, in which we are conspicuously lacking." ${ }^{33}$ University of San Francisco

San Francisco, California

42Thomson, "Physician-Assisted Suicide," 517.

${ }^{43}$ Anscombe, "Modern Moral Philosophy," 1. 